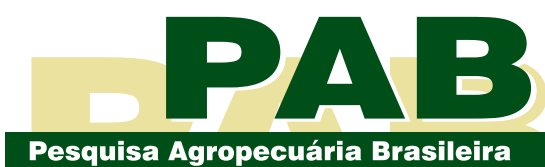

ISSN 1678-3921

Journal homepage: www.embrapa.br/pab

For manuscript submission and journal contents, access: www.scielo.br/pab

\section{Ammonium chloride as an alternative source of nitrogen for sugarcane during two consecutive cycles}

\begin{abstract}
The objective of this work was to evaluate the effect of the application of ammonium chloride as a nitrogen source for sugarcane (Saccharum sp.) on the development of the crop's shoot and roots during two consecutive cycles. The experiment was conducted on a Typic Hapludox in the first and second sugarcane ratoons. The treatments consisted of four $\mathrm{N}$ doses $(50,100,150$, and $\left.200 \mathrm{~kg} \mathrm{ha}^{-1}\right)$ applied as ammonium chloride $\left(\mathrm{NH}_{4} \mathrm{Cl}\right)$, besides a control, without the application of $\mathrm{N}$. The increase in the $\mathrm{NH}_{4} \mathrm{Cl}$ dose increased in up to three times soil electrical conductivity in the layer of $0.0-0.2 \mathrm{~m}$, with a consequent increase in the concentration of chlorine in leaves. In the second cycle, the contents of chlorine increased in $1,900 \mathrm{mg} \mathrm{kg}^{-1}$ in the leaf with the application of $200 \mathrm{mg} \mathrm{kg}^{-1} \mathrm{NH}_{4} \mathrm{Cl}$, when compared with the control. In the first cycle, the application of $\mathrm{NH}_{4} \mathrm{Cl}$ doses above $200 \mathrm{~kg} \mathrm{ha}^{-1} \mathrm{~N}$ promoted a decrease in shoot productivity. In both cycles, there was no effect of the $\mathrm{NH}_{4} \mathrm{Cl}$ doses on root dry matter. High doses of $\mathrm{NH}_{4} \mathrm{Cl}$, in consecutive sugarcane cycles, result in a decrease in the productivity of stalks for processing.
\end{abstract}

Index terms: Saccharum, electrical conductivity, nitrogen fertilization, root system, stalk productivity.

\section{Cloreto de amônio como fonte alternativa de nitrogênio para cana-de-açúcar durante dois ciclos consecutivos}

Resumo-O objetivo deste trabalho foi avaliar o efeito da aplicação de cloreto
de amônio como fonte de nitrogênio para cana-de-açúcar (Saccharum sp.)
no desenvolvimento da parte aérea e radicular da cultura durante dois ciclos
consecutivos. O experimento foi conduzido em Latossolo Vermelho distrófico
típico nos ciclos de primeira e segunda soqueira. Os tratamentos consistiram
de quatro doses de $\mathrm{N}\left(50,100,150\right.$ e $\left.200 \mathrm{~kg} \mathrm{ha}^{-1}\right)$ aplicadas na forma de cloreto
de amônio $\left(\mathrm{NH}_{4} \mathrm{Cl}\right)$, além do controle, sem aplicação de $\mathrm{N}$. O aumento da dose
de $\mathrm{NH}_{4} \mathrm{Cl}$ elevou em até três vezes a condutividade elétrica do solo na camada
de $0,0-0,2 \mathrm{~m}$, com consequente aumento na concentração de cloro nas folhas.
No segundo ciclo, os teores de cloro aumentaram em $1.900 \mathrm{mg} \mathrm{kg}^{-1}$ na folha
com a aplicação de $200 \mathrm{mg} \mathrm{kg}^{-1}$ de $\mathrm{NH}_{4} \mathrm{Cl}$, em comparação ao controle. No
primeiro ciclo, a aplicação de doses de $\mathrm{NH}_{4} \mathrm{Cl}$ acima de $200 \mathrm{~kg}^{-1}$ de $\mathrm{N}$
promoveu queda na produtividade de colmos. Em ambos os ciclos, não houve
efeito das doses de $\mathrm{NH}_{4} \mathrm{Cl}$ na fitomassa seca de raízes. Elevadas doses de
$\mathrm{NH}_{4} \mathrm{Cl}$, em ciclos consecutivos da cana-de-açúcar, resultam em decréscimos
na produtividade de colmos industrializáveis.

Termos para indexação: Saccharum, condutividade elétrica, adubação nitrogenada, sistema radicular, produtividade de colmos. 


\section{Introduction}

Brazil is the world's largest sugarcane (Saccharum spp.) producer, accounting for $35 \%$ of the crop's output, and also the leading sugar producer and exporter. According to Companhia Nacional de Abastecimento (Acompanhamento..., 2017), sugarcane production in the 2016/2017 harvest totaled 657 million tons in a 9 million hectare area, with an average yield of $73 \mathrm{Mg}$ $\mathrm{ha}^{-1}$. However, studies indicate that sugarcane yield is still far below the genetic potential of the currently used cultivars, which can produce above $300 \mathrm{Mg} \mathrm{ha}^{-1}$ stalks for processing (Waclawovsky et al., 2010).

In general, for their development, crops require high nitrogen doses, which are one of the main factors responsible for increasing agricultural production. Although $\mathrm{N}$ composes, on average, $1 \%$ of total plant dry matter, its deficiency compromises plant growth and crop yield. In Brazil, the $\mathrm{N}$ doses applied to sugarcane crops are relatively low, representing one third of the ones applied in other producing countries (Robinson et al., 2011). According to these authors, the average $\mathrm{N}$ application in Australia has increased from 100 to $200 \mathrm{~kg} \mathrm{ha}^{-1}$ in the last 30 years, whereas in India, China, and Pakistan extreme doses range from 400 to $750 \mathrm{~kg} \mathrm{ha}^{-1} \mathrm{~N}$.

It should be noted that Brazil has become increasingly dependent on imported fertilizers, which currently account for $75 \%$ of total $\mathrm{N}$ demand, ranking the country as the fourth major importer of feedstock for the production of $\mathrm{N}$ fertilizers. Besides its costs, $\mathrm{N}$ use in agriculture causes environmental concerns, since the uptake by crops of the applied $\mathrm{N}$ fertilizer is less than 40\% (Fortes et al., 2011; Franco et al., 2011). Most applied $\mathrm{N}$ is lost into the atmosphere as ammonia gas and nitrous oxide or even leached as a nitrate anion (Börjesson et al., 2009).

Losses are even more worrisome in sugarcane crops, whose residues on soil surface reach $15 \mathrm{Mg} \mathrm{ha}^{-1}$ after the mechanical harvest of raw cane; this hinders the incorporation of $\mathrm{N}$ to the soil and increases the risks of $\mathrm{N}$ losses by the volatilization of ammonia gas, especially urea, due to the high susceptibility of the nutrient to enzymatic hydrolysis by the action of urease when it is applied superficially and in direct contact with plant residues (Mariano et al., 2012, 2016). Therefore, studies on new $\mathrm{N}$ sources are crucial, which may increase $\mathrm{N}$ use efficiency by sugarcane.
Ammonium chloride, a byproduct of sodium bicarbonate production, contains 25 and $65 \% \mathrm{~N}$ and chlorine, respectively, and can be used as a nitrogen fertilization source in crops (Ashraf et al., 2005; Megda et al., 2012). Vieira et al. (2010) evaluated the response of sugarcane to ammonium chloride doses and found an increase in yield in the first year of application, followed by a decrease in stalk and sugar production per area in the next cycle, when the residual effect of that source was assessed. Studies have shown that high doses of ammonium chloride may decrease crop growth (Megda et al., 2014; Vieira-Megda et al., 2015; Leite et al., 2016), requiring further investigation on its viability as a $\mathrm{N}$ source. Negative effects of the chloride ion on crop development are mainly related to the increase in the osmotic potential of the soil solution, which induces plants to hydric stress and also causes a direct toxic effect, mainly on the enzymatic and membrane systems (Alves et al., 2011). Therefore, since sugarcane is a semi-perennial crop, new studies should investigate its responses to $\mathrm{N}$ fertilization with ammonium chloride, not only within one, but also within consecutive cycles.

The objective of this work was to evaluate the effect of the application of ammonium chloride as a nitrogen source for sugarcane on the development of the crop's shoot and roots during two consecutive cycles.

\section{Materials and Methods}

The experiment was conducted in a commercial area of first and second sugarcane ratoons during the 2009/2010 and 2010/2011 crop seasons, in the region of Piracicaba, in the state of São Paulo, Brazil (22 $35^{\circ}$ "S, $47^{\circ} 37^{\prime \prime} \mathrm{W}$, at an altitude of $619 \mathrm{~m}$ ).

The soil was classified as a Latossolo Vermelho distrófico típico (Santos et al., 2013), i.e., a Typic Hapludox, according to Soil Survey Staff (2014). Two correctives $-2 \mathrm{Mg}^{-1}$ dolomitic limestone and $2 \mathrm{Mg}$ ha $^{-1}$ agricultural gypsum - were incorporated into the soil by heavy harrowing. The cultivar SP89-1115 of sugarcane was planted on March 8, 2008, using two seedlings per meter, providing a distribution of 17-20 buds per meter of furrow, at a depth of $0.15 \mathrm{~m}$. Mineral fertilization was carried out with the application of potassium chloride and simple superphosphate into the planting groove, in order to supply $120 \mathrm{~kg} \mathrm{ha}^{-1}$ $\mathrm{K}_{2} \mathrm{O}$ and $120 \mathrm{~kg} \mathrm{ha}^{-1} \mathrm{P}_{2} \mathrm{O}_{5}$, respectively. The cane plant

Pesq. agropec. bras., Brasília, v.54, e00329, 2019

DOI: 10.1590/S1678-3921.pab2019.v54.00329 
was harvested mechanically without burning events in June 2009, and crop residues (pointers, leaves, and pieces of stalk) were deposited on soil surface.

Soil chemical attributes were analyzed at the depths of $0.0-0.2$ and $0.2-0.4 \mathrm{~m}$, according to Raij et al. (2001). For both layers, the obtained values were: 4.6 $\mathrm{pH}$ in $\mathrm{CaCl}_{2} 0.01 \mathrm{~mol} \mathrm{~L}^{-1}, 29 \mathrm{mg} \mathrm{dm}^{-3}$ phosphorus resin, $5.0 \mathrm{mmol}_{\mathrm{c}} \mathrm{dm}^{-3} \mathrm{Al}$ extracted with potassium chloride, and $0.5 \mathrm{mg} \mathrm{dm}^{-3} \mathrm{Zn}$. For the first and second layers: 39 and $33 \mathrm{~g} \mathrm{dm}^{-3}$ organic matter by the colorimetric method, respectively; 4.3 and $4.6 \mathrm{mmol}_{\mathrm{c}} \mathrm{dm}^{-3}$ potassium extracted by ion-exchange resin; 13 and 29 $\mathrm{mmol}_{\mathrm{c}} \mathrm{dm}^{-3} \mathrm{Ca} ; 6.0$ and $12 \mathrm{mmol}_{\mathrm{c}} \mathrm{dm}^{-3} \mathrm{Mg}$ extracted by ion-exchange resin; 72 and $80 \mathrm{mmol}_{\mathrm{c}} \mathrm{dm}^{-3} \mathrm{H}+\mathrm{Al}$ by the SMP method; 0.24 and $0.17 \mathrm{mg} \mathrm{dm}^{-3} \mathrm{~B} ; 2.0$ and $3.8 \mathrm{mg} \mathrm{dm}^{-3} \mathrm{Cu}$; 76 and $67 \mathrm{mg} \mathrm{dm}^{-3} \mathrm{Fe} ; 6.9$ and $5.3 \mathrm{mg}$ $\mathrm{dm}^{-3} \mathrm{Mn} ; 72$ and $80 \mathrm{mmol}_{\mathrm{c}} \mathrm{dm}^{-3} \mathrm{H}+\mathrm{Al} ; 95.3$ and 125.6 $\mathrm{mmol}_{\mathrm{c}} \mathrm{dm}^{-3}$ cation exchange capacity at $\mathrm{pH} 7.0$; sum of bases of 23.3 and $45.6 \mathrm{mmol}_{\mathrm{c}} \mathrm{dm}^{-3}$; and base saturation of 24 and $36 \%$.

The experimental design was a randomized complete block design with four replicates and $202.5 \mathrm{~m}^{2}$-experimental plots, each containing 10 rows of $15 \mathrm{~m}$ with a row spacing of $1.5 \mathrm{~m}$.

The treatments consisted of four $\mathrm{N}$ doses $(50,100$, 150 , and $200 \mathrm{~kg} \mathrm{ha}^{-1}$ ) applied in the form of ammonium chloride, besides a control, without $\mathrm{N}$ application. The $\mathrm{N}$ source was applied manually on the residual sugarcane straw, which totaled $17.2 \mathrm{Mg} \mathrm{ha}^{-1}$, in a band, $0.2 \mathrm{~m}$ away from the crop row.

In addition, $90 \mathrm{~kg} \mathrm{ha}^{-1} \mathrm{~K}_{2} \mathrm{O}$ in the form of $\mathrm{KCl}$ were applied in all treatments. Due to the high P content of $29 \mathrm{mg} \mathrm{dm}^{-3}$ in the soil, phosphate fertilization was not carried out. Fertilization treatments were applied on September 28, 2009, 90 days after harvesting (DAH), on the first ratoon; and on October 6, 2010, $150 \mathrm{DAH}$, on the second ratoon.

Soil electrical conductivity (EC) was determined at 60 days after fertilization (DAF) in the first ratoon and at $30 \mathrm{DAF}$ in the second, at the layers of $0.0-0.2$ and $0.2-0.4 \mathrm{~m}$, as proposed by Raij et al. (2001), in order to express the total concentration of salts $\left(\mu \mathrm{S} \mathrm{cm}^{-1}\right)$ in the soil solution. It should be pointed out that EC was determined at $30 \mathrm{DAF}$ in the second ratoon to reduce the time between its evaluation and fertilization, in order to estimate the concentration of salts in the rhizosphere before total absorption by plants.
In both harvests, in February 2010 and 2011, at 60 DAF, diagnostic leaves were collected to determine leaf chlorine concentration. Five leaves at position $+1(\mathrm{~F}+1)$, identified according to the Kuijper system, were randomly collected in each plot, comprising a composite sample. The samples were dried in a forcedair circulation oven at $65^{\circ} \mathrm{C}$ and ground in a Wiley-type mill (30-mm mesh), and chlorine concentrations were obtained according to Malavolta et al. (1997), using the silver nitrate titration method.

The dry matter production of the sugarcane shoot and root system was determined at the end of the vegetative cycle of the second ratoon, at 210 DAF. To evaluate shoot dry matter, all vegetal material was collected in $2 \mathrm{~m}$ of each row, one sample per plot. The number of tillers in the samples was counted, the dry matter of the material was quantified, and the average dry matter per tiller was obtained. The tillers were also counted in $15 \mathrm{~m}$ of each row (three 5 -m segments) per plot, and the average number of tillers per hectare (considering that 1 ha with a row spacing of $1.5 \mathrm{~m}$ has 6,667 linear meters) was determined. Stalk yield $\left(\mathrm{Mg} \mathrm{ha}^{-1}\right)$ was calculated by multiplying the number of tillers per hectare by the average dry matter of tillers estimated in $2 \mathrm{~m}$.

After weighing the shoot material, the samples with natural moisture were crushed in a mechanical grinder. Subsamples of this material were packed in hermetically sealed plastic bags, weighed on an analytical scale, and dried in a ventilated oven at $65^{\circ} \mathrm{C}$ to obtain plant moisture and dry matter.

Root dry matter was evaluated in the second cycle in May 2011, at 230 DAF, as described by Otto et al. (2009). Belowground rhizomes were also sampled in $1 \mathrm{~m}$ of each row planted with sugarcane. Roots and rhizomes were separated from the soil using 2-mm mesh sieves, and, in the laboratory, root samples were washed in 1-mm mesh sieves and dried at $65^{\circ} \mathrm{C}$ for moisture determination.

Stalk yield per hectare, i.e., tons of sugarcane stalks per hectare (TSH), was evaluated in May 2010 and August 2011, at 240 and $300 \mathrm{DAF}$, in the first and second cycles, respectively, by mechanical cutting and weighing of the chopped cane in an instrumented truck. Four rows per plot (second, third, fourth, and fifth rows) were collected, totaling 60 linear meters per plot. The results of each plot were extrapolated to 1 ha considering $6,667 \mathrm{~m}$ of cane row per hectare. 
The results were subjected to the analysis of variance using the F-test, at $95 \%$ probability, with the SAS software (SAS Institute Inc., Cary, NC, USA). Subsequently, for significant causes of variation, the regression analysis was applied to verify the effect of $\mathrm{N}$ doses.

\section{Results and Discussion}

The increase in the $\mathrm{N}$ dose applied in the form of ammonium chloride reduced TSH in the two cycles evaluated, represented by a decreasing linear equation (Figure 1). In the first cycle, an average yield of 105 $\mathrm{Mg} \mathrm{ha}^{-1}$ was reached with the control, and one of 75 $\mathrm{Mg} \mathrm{ha}^{-1}$ with the dose of $200 \mathrm{~kg} \mathrm{ha}^{-1} \mathrm{~N}$.

There was a reduction in stalk yield from the first to the second ratoon, from 89 to $74 \mathrm{Mg} \mathrm{ha}^{-1}$ when applying the control and $200 \mathrm{~kg} \mathrm{ha}^{-1} \mathrm{~N}$, respectively. These results may be attributed to the high concentration of salts in the rhizosphere in the initial phase of crop development, in the first and second cycles, when the plants had $30 \mathrm{~cm}$ of height on average, mainly due to chlorine excess in the soil, since the $\mathrm{Cl}^{-}$anion accounts for $65 \%$ of ammonium chloride composition. In the control, EC values were rather high, averaging $70 \mu \mathrm{S}$ $\mathrm{cm}^{-1}$ at 60 DAF in the first cycle and above $100 \mu \mathrm{S} \mathrm{cm}^{-1}$ at $30 \mathrm{DAF}$ in the second one, increasing considerably with the increase of ammonium chloride doses (Figure 2).

The dose of $200 \mathrm{~kg} \mathrm{ha}^{-1}$ ammonium chloride corresponded to $520 \mathrm{~kg} \mathrm{ha}^{-1} \mathrm{Cl}^{-}$plus $60 \mathrm{~kg} \mathrm{ha}^{-1} \mathrm{Cl}^{-}$ added as $\mathrm{KCl}\left(90 \mathrm{~kg} \mathrm{ha}^{-1} \mathrm{~K}_{2} \mathrm{O}\right)$. In general, plants take up a high amount of chlorine, an important anti-cation along with $\mathrm{K}^{+}$(Taiz et al., 2017). However, in excess, chloride can dissipate the cytosolic $\mathrm{pH}$, damaging several enzymatic reactions. Vieira et al. (2010) and Megda et al. (2012) evaluated the residual effect of ammonium chloride doses on the yield of sugarcane cultivated on a Typic Hapludox and, despite the increase in shoot yield observed in the first experimental year, there was a decrease in crop shoot with the increase of the applied doses. In the following harvest, when the residual effect of ammonium chloride doses was assessed, there was a significant reduction in crop yield. As sugarcane is considered moderately sensitive to soil salinity (Santana et al., 2007), the decrease in shoot yield at 60 DAF due to ammonium chloride doses may have been aggravated by the excess of salts in the rhizosphere.

In addition, climatic factors must be taken into account, since they have great influence on stalk yield. Although rainfall $(1,862 \mathrm{~mm})$ was intense in the 2009/2010 crop season, fertilization was carried out in the second ten-day period of September, when rainfall was low, averaging $9 \mathrm{~mm}$ (Figure 3); there was also water deficit in November. The reports found in the literature show that, when water availability is reduced in the soil, the response to fertilization decreases due to hydric stress (Otto et al., 2011). However, according
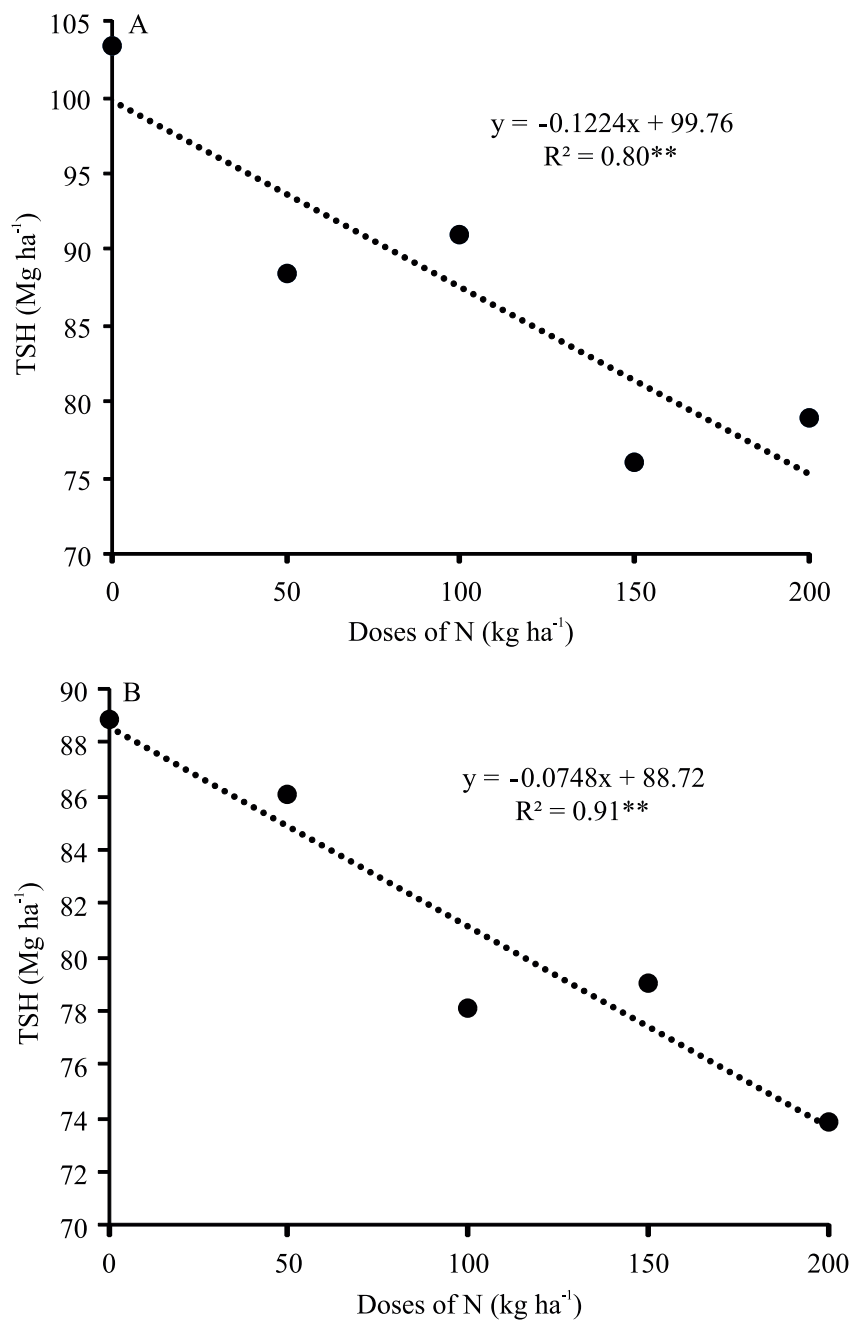

Figure 1. Tons of sugarcane stalks per hectare (TSH) in the first sugarcane (Saccharum spp.) ratoon, in the 2009/2010 harvest (A), and in the second ratoon, in 2010/2011 (B), as a function of the application of $\mathrm{N}$ doses as ammonium chloride $\left(\mathrm{NH}_{4} \mathrm{Cl}\right)$. $* *$ Significant at $5 \%$ probability. 
to Inman-Bamber \& Smith (2005), a well-distributed annual rainfall of $1,000 \mathrm{~mm}$ is enough to obtain high sugarcane yields. It should be pointed out that chlorine is highly mobile in the soil and, depending on rain volume, it can be partially leached, mainly at higher doses of ammonium chloride; however, due to the low rainfall observed at fertilization, plants probably absorbed large amounts of that nutrient.

Studies have shown a reduction in plant growth and crop yield under saline stress (Jacobs \& Timmer, 2005). These authors attributed the decrease in yield to the increase in osmotic pressure and the reduction in the hydric potential of the soil solution generated by the excess of ions in the rhizosphere, hindering water uptake by plant roots. Water is an essential factor for cell expansion, and its limitation implies in a lower cell and tissue growth and leaf area, affecting yield.

In the second ratoon cycle, rainfall totaled 1,550 $\mathrm{mm}$ and, although temperature and solar radiation allowed a high potential evapotranspiration of the crop, water storage in the soil was low during initial crop development and part of the vegetative phase (Cardozo \& Sentelhas, 2013), limiting the real evapotranspiration (Figure 3).
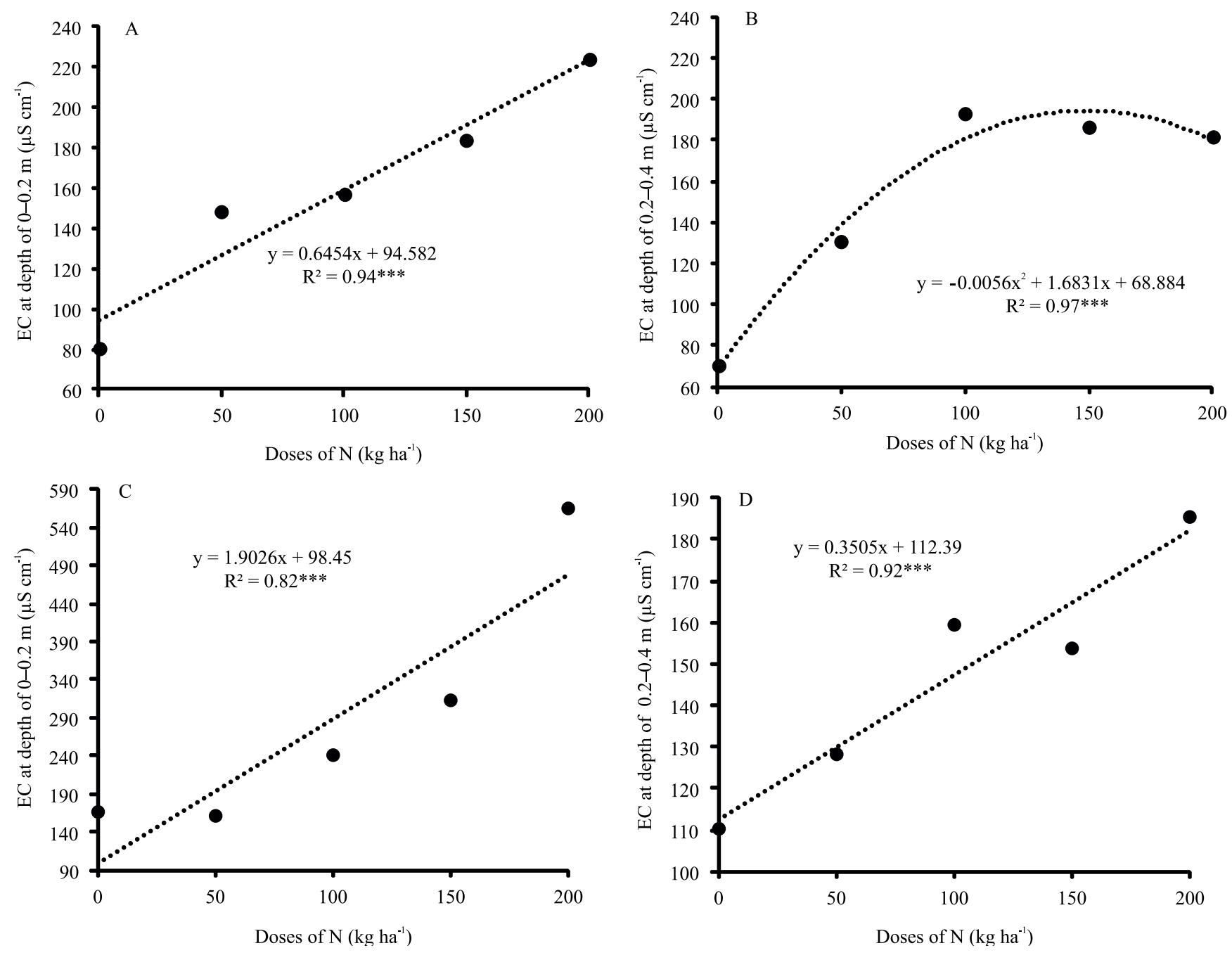

Figure 2. Electrical conductivity $(\mathrm{EC})$ of the soil solution as a function of the application of $\mathrm{N}$ doses as ammonium chloride $\left(\mathrm{NH}_{4} \mathrm{Cl}\right)$ at the depths of $0.0-0.2 \mathrm{~m}(\mathrm{~A})$ and $0.2-0.4 \mathrm{~m}(\mathrm{~B})$ at 60 days after fertilization (DAF) in the first sugarcane (Saccharum spp.) ratoon, in the $2009 / 2010$ harvest, and at $0.0-0.2 \mathrm{~m}$ (C) and $0.2-0.4 \mathrm{~m}$ (D) at 30 DAF in the second sugarcane ratoon, in $2010 / 2011 . * * *$ Significant at $1 \%$ probability. 
The increase in ammonium chloride doses was accompanied by a linear increase in soil EC in both cycles and depths evaluated (Figure 2). In the first cycle, at the depth of $0.0-0.2 \mathrm{~m}$, at $60 \mathrm{DAF}$, the values of EC ranged from 80 to $220 \mu \mathrm{S} \mathrm{cm}^{-1}$ for the control and the highest applied dose, respectively. In the soil layer of $0.2-0.4 \mathrm{~m}$, there was a quadratic effect of ammonium chloride doses on EC, which ranged from 70 to $190 \mu \mathrm{S} \mathrm{cm}^{-1}$ for the control and the highest dose
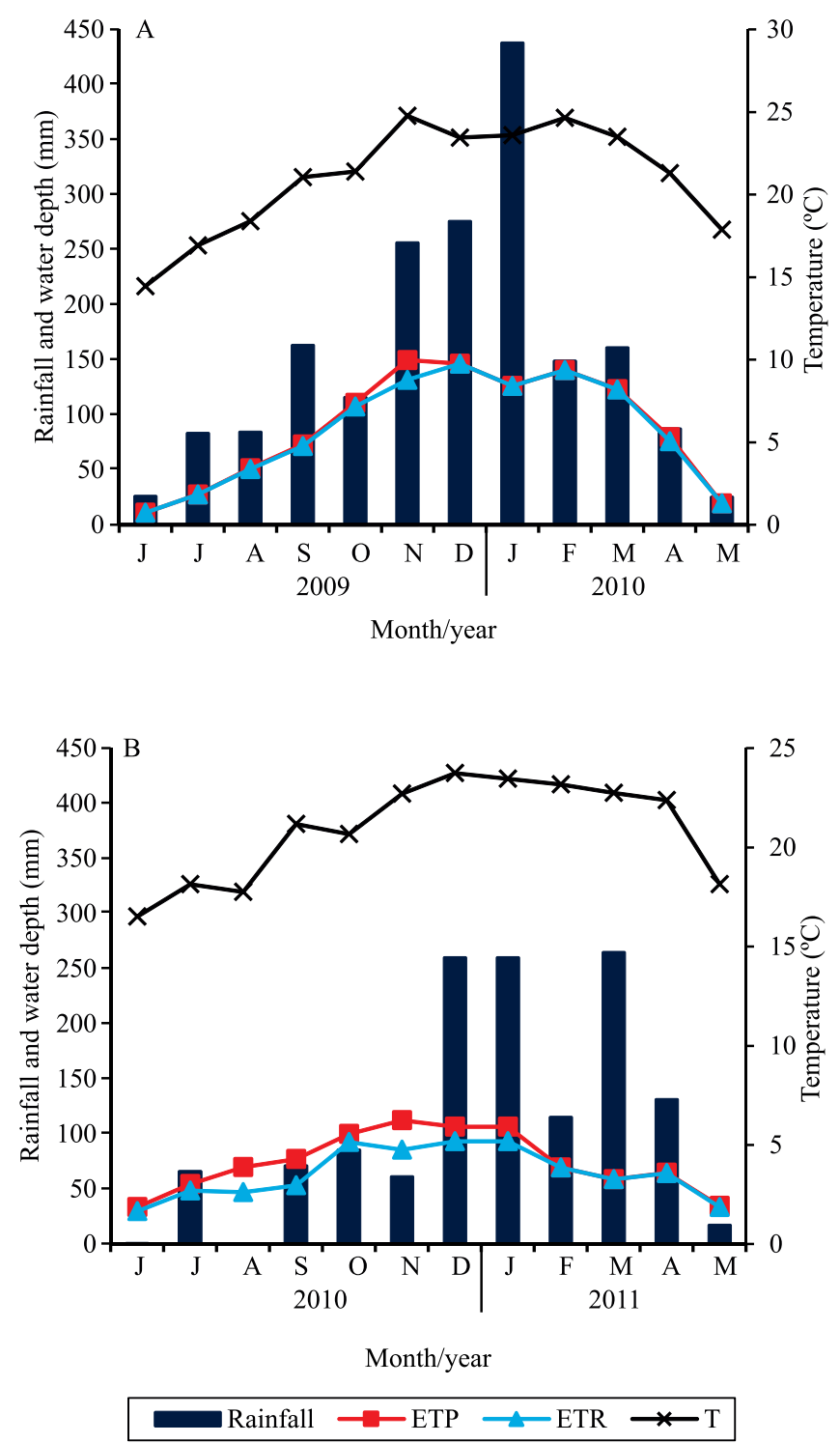

Figure 3. Climatic water balance in the first sugarcane (Saccharum spp.) ratoon, in the 2009/2010 harvest (A), and in the second ratoon, in 2010/2011 (B). ETp, potential evapotranspiration; ETr, real evapotranspiration; and T, temperature. of $200 \mathrm{~kg} \mathrm{ha}^{-1}$, indicating the translocation of part of the fertilizer to the soil subsurface layer.

In the second cycle, EC at the 0.0-0.2-m layer was on average three times higher than that in the first cycle, evidencing that a large amount of salts accumulated in the soil arable layer from one cycle to the next. The EC values obtained in the subsurface layer of $0.2-0.4$ $\mathrm{m}$ in the second cycle were similar to those of the first one, probably due to the lower rainfall volume in the 2010/2011 crop season, reducing the leaching of ions to deeper layers. According to Santana et al. (2007), yield decrease in sugarcane stalks can reach $50 \%$ in soils with high EC. The authors reported a linear evapotranspiration reduction of up to $20 \%$ under greenhouse conditions, as well as a dry matter decrease in sugarcane roots and shoots, regardless of soil texture.

There was a linear increase in chlorine contents in the diagnostic leaves with the increase of the ammonium chloride doses in the two cycles evaluated (Figure 4). In the first ratoon, at $60 \mathrm{DAF}$, the control plot had a high chlorine content in $\mathrm{F}+1$, suggesting a high content of this nutrient in the soil used in the experiment due to previous fertilization, mainly with $\mathrm{KCl}$. At the highest ammonium chloride dose, chlorine increased by $600 \mathrm{mg} \mathrm{kg}^{-1}$ in the diagnostic leaf, when compared with the control plants.

At $30 \mathrm{DAF}$ in the second ratoon, $\mathrm{Cl}^{-}$content at $\mathrm{F}+1$ was approximately $9,000 \mathrm{mg} \mathrm{kg}^{-1}$. These results also suggest a high chlorine content in the soil from the previous cycle. Symptoms of $\mathrm{Cl}^{-}$toxicity are more common than deficiency, and tolerance depends on the species. For example, the most sensitive crops may show symptoms at $3,000 \mathrm{mg} \mathrm{kg}^{-1}$ dry matter, and the most tolerant ones at 20,000 $\mathrm{mg} \mathrm{kg}^{-1}$ (Furlani, 2004). As previously mentioned, the sugarcane crop is considered moderately sensitive to high contents of salinity ions in the soil, such as $\mathrm{Cl}^{-}$(Santana et al., 2007). According to Bethke \& Drew (1992), the passive uptake process of chlorine can lead to its accumulation in large amounts in the shoots, causing enzymatic disturbances or unbalance of the electrochemical potential of cells, leading to a higher energy expenditure and causing toxicity, which decrease yield.

In the second ratoon cycle, the increase in ammonium chloride doses promoted a quadratic effect on stalk dry matter at 210 DAF. For both cycles, the doses of 100 and $150 \mathrm{~kg} \mathrm{ha}^{-1} \mathrm{~N}$ resulted in the highest 
yield of $16 \mathrm{Mg} \mathrm{ha}^{-1}$, while $200 \mathrm{~kg} \mathrm{ha}^{-1} \mathrm{~N}$ decreased yield (Figure 5). Total dry matter accumulation of shoots, however, showed a linear increase of $2.2 \mathrm{Mg} \mathrm{ha}^{-1}$, when comparing the yield of $21.3 \mathrm{Mg} \mathrm{ha}^{-1}$, obtained with the control, with that of $23.5 \mathrm{Mg} \mathrm{ha}^{-1}$, with the dose of 200 $\mathrm{kg} \mathrm{ha}^{-1} \mathrm{~N}$.

Presented as a powder, ammonium chloride has a very fine particle size, which confers it a high solubility; under low humidity conditions, this salt accumulates in the most arable layer of the soil, causing hydric stress to fertilized plants and consequent soil water loss (Munns \& Tester, 2008). This explains why, despite the significant increase in stalk dry matter at $210 \mathrm{DAF}$,
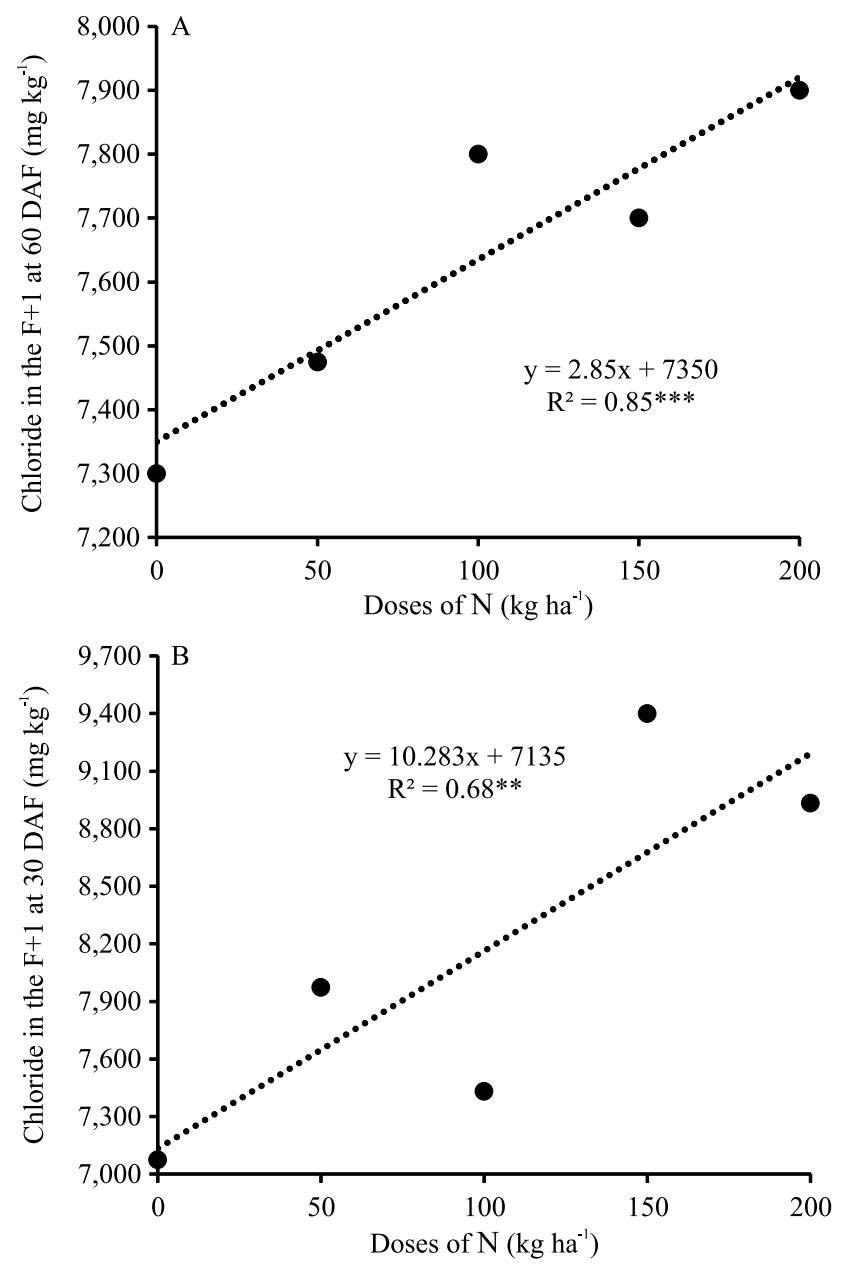

Figure 4. Chloride concentration in the diagnostic leaf $(\mathrm{F}+1)$ of sugarcane (Saccharum spp.) as a function of the application of $\mathrm{N}$ doses as ammonium chloride $\left(\mathrm{NH}_{4} \mathrm{Cl}\right)$ at 60 days after fertilization (DAF) in the first sugarcane ratoon, in 2009/2010 (A), and at 30 DAF in the second sugarcane ratoon, in 2010/2011 (B). *** and **Significant at 1 and 5\% probability, respectively. the yield of stalks with natural moisture, for future processing, decreased with the increase of ammonium chloride doses at 300 DAF. Other studies have also shown a negative effect of ammonium chloride on crop yield, but the $\mathrm{N}$ dose studied was $100 \mathrm{~kg} \mathrm{ha}^{-1}$ (Leite et al., 2016; Mariano et al., 2016). Furthermore, $\mathrm{K}^{+}$is essential to transport carbohydrates to stalks, which is directly related to water accumulation in this compartment. Since the $\mathrm{Cl}^{-}$ion is an important antication, excess of $\mathrm{Cl}^{-}$may have affected negatively sugar transport and stalk moisture.

The increase in the ammonium chloride dose increased $\mathrm{N}$ accumulation in sugarcane shoots
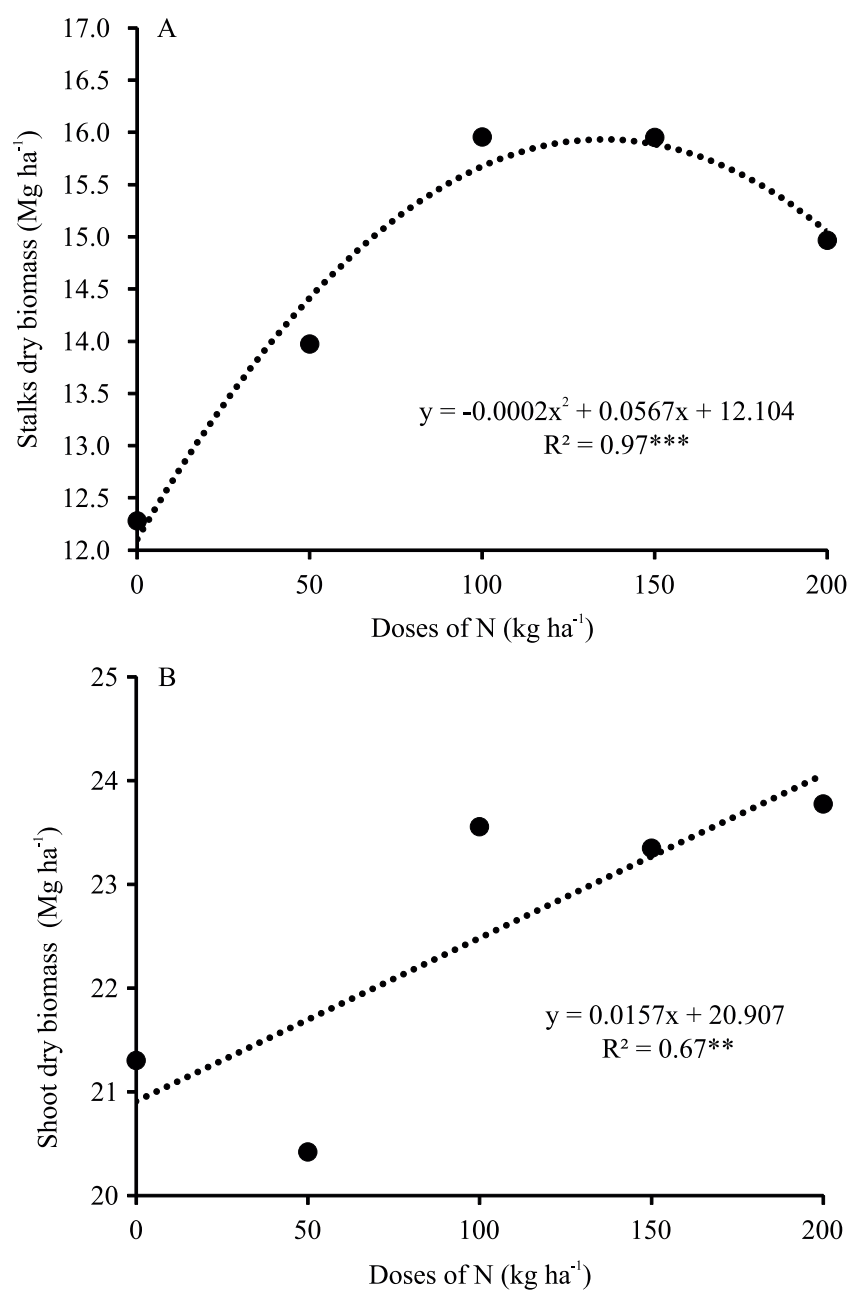

Figure 5. Dry matter of stalks (A) and total shoot (tillers, dry leaves, and pointers) (B) of sugarcane (Saccharum spp.) as a function of the application of $\mathrm{N}$ doses as ammonium chloride $\left(\mathrm{NH}_{4} \mathrm{Cl}\right)$ in the in the second sugarcane ratoon, in 2010/2011 harvest. *** and **Significant at 1 and 5\% probability, respectively. 
and stalks (Figure 6), and, in spite of an increase in $\mathrm{N}$ accumulation in the shoots, it was inversely proportional to stalk yield. Franco et al. (2010), Mariano et al. (2015), Vieira-Megda et al. (2015), and Leite et al. (2016) found similar results studying $\mathrm{N}$ sources at the dose of $100 \mathrm{~kg} \mathrm{ha}^{-1}$. These authors were unanimous regarding the need for new studies including other doses of ammonium chloride and with the reapplication of this source in consecutive cycles.

The increase in ammonium chloride doses increased linearly the dry matter of rhizomes, accompanied by an increase in $\mathrm{N}$ accumulation in this compartment,
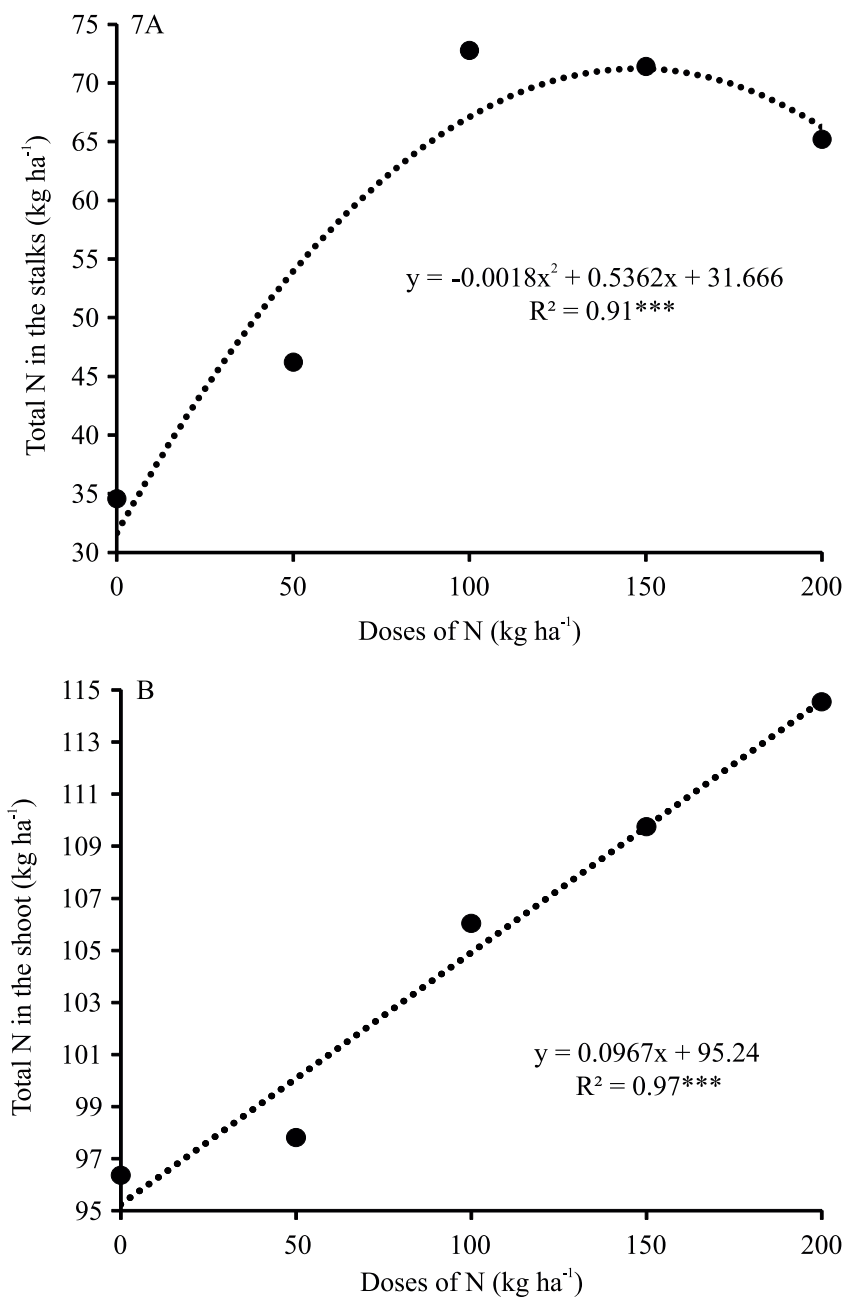

Figure 6. Nitrogen accumulation in the stalks (A) and in total shoot (stalks, dry leaves, and pointers) (B) of sugarcane (Saccharum spp.) as a function of the application of $\mathrm{N}$ doses as ammonium chloride $\left(\mathrm{NH}_{4} \mathrm{Cl}\right)$ in the second sugarcane ratoon, in the $2010 / 2011$ harvest. ***Significant at $1 \%$ probability. representing an important source of nutrient reserves for subsequent regrowth (Figure 7). Mariano et al. (2016) compared the effect of ammonium chloride with that of other $\mathrm{N}$ sources at the dose $100 \mathrm{~kg} \mathrm{ha}^{-1}$ on sugarcane shoot yield and nutrient accumulation on two soil types - Typic Hapludox and Typic Eutrustox. The authors found that, in a single crop year, ammonium chloride did not increase plant dry matter on both soils; however, it increased $\mathrm{N}$ content in the shoot when compared with the control on a Typic Hapludox. Vieira-Megda et al. (2015) evaluated N contribution from fertilizers at the dose $100 \mathrm{~kg} \mathrm{ha}^{-1} \mathrm{~N}$ using the
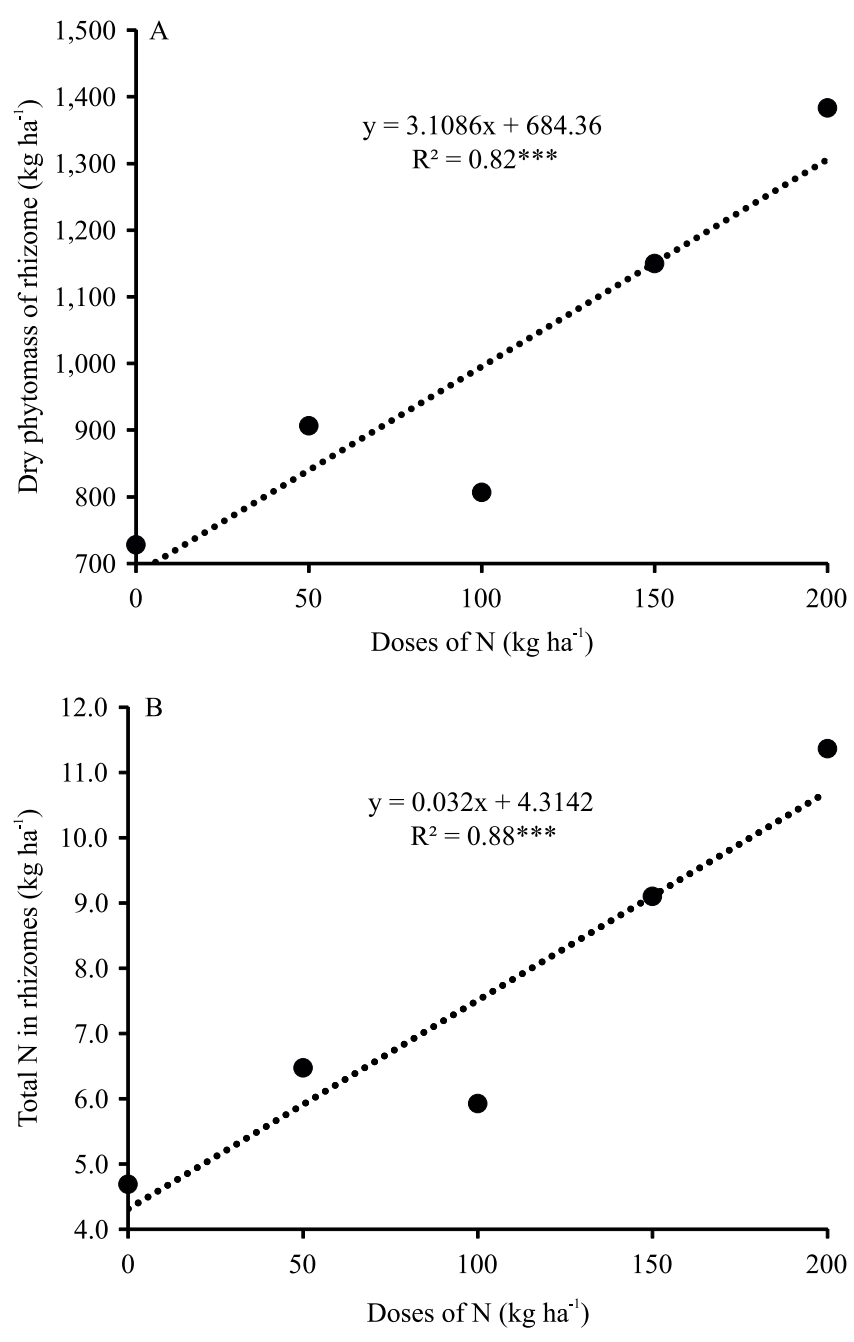

Figure 7. Dry phytomass of rhizomes (A) and total $\mathrm{N}$ in rhizomes (B) of sugarcane (Saccharum spp.) as a function of the application of $\mathrm{N}$ doses as ammonium chloride $\left(\mathrm{NH}_{4} \mathrm{Cl}\right)$ in the second sugarcane ratoon, in the 2010/2011 harvest. $* * *$ Significant at $1 \%$ probability. 
${ }^{15} \mathrm{~N}$ tracer technique and reported no difference between sources regarding dry shoot and roots and $\mathrm{N}$ accumulation in these compartments during the first ratoon cycle. According to the latter authors, further studies are necessary to better understand the effect of ammonium chloride as a $\mathrm{N}$ source for sugarcane.

\section{Conclusions}

1. The increase in ammonium chloride doses as a source of nitrogen for sugarcane (Saccharum spp.) excessively increases the electrical conductivity of the soil solution, with consequent uptake by the crop and accumulation of chloride in the shoots.

2. The application of ammonium chloride does not affect the development of the root system of sugarcane, nor, consequently, $\mathrm{N}$ uptake and shoot dry matter accumulation.

3. High doses of nitrogen applied as ammonium chloride in consecutive cycles of the sugarcane crop result in a decrease in the yield of stalks for processing.

\section{Acknowledgments}

To Fundação de Amparo à Pesquisa do Estado de São Paulo (Fapesp), for scholarships (grant numbers 2009/10192-9, 2009/04691-2, and 2009/12537-3); to Conselho Nacional de Desenvolvimento Científico e Tecnológico (CNPq), for financial support; and to Usina Iracema (Grupo São Martinho), for support in field activities.

\section{References}

ACOMPANHAMENTO DA SAFRA BRASILEIRA [DE] CANA-DE-AÇÚCAR: safra 2016/17: quarto levantamento, v.3, n.4, abril 2017. Available at: <https://www.conab.gov.br/infoagro/safras/cana/boletim-da-safra-de-cana-de-acucar $>$. Accessed on: Aug. 122017.

ALVES, F.A.L.; FERREIRA-SILVA, S.L.; SILVEIRA, J.A.G. da; PEREIRA, V.L.A. Efeito do $\mathrm{Ca}^{2+}$ externo no conteúdo de $\mathrm{Na}^{+}$e $\mathrm{K}^{+}$em cajueiros expostos a salinidade. Revista Brasileira de Ciências Agrárias, v.6, p.602-608, 2011. DOI: https://doi.org/10.5039/agraria.v6i4a1257.

ASHRAF, M.Y.; ALVI, A.K.; SARWAR, G.; QURESHI, M.S.; ASHRAF, M.; HUSSAIN, M. Effect of ammonium chloride on the growth and nutrient uptake by cotton grown in alkaline soil. Agrochimica, v.49, p.153-164, 2005.

BETHKE, P.C.; DREW, M.C. Stomatal and nonstomatal components to inhibition of photosynthesis in leaves of Capsicum annuum during progressive exposure to $\mathrm{NaCl}$ salinity. Plant Physiology, v.99, p.219-226, 1992.

BÖRJESSON, P. Good or bad bioethanol from a greenhouse gas perspective - what determines this? Applied Energy, v.86, p.589594, 2009. DOI: https://doi.org/10.1016/j.apenergy.2008.11.025.

CARDOZO, N.P.; SENTELHAS, P.C. Climatic effects on sugarcane ripening under the influence of cultivars and crop age. Scientia Agricola, v.70, p.449-456, 2013. DOI: https://doi.org/10.1590/S0103-90162013000600011.

FORTES, C.; TRIVELIN, P.C.O.; VITTI, A.C.; FERREIRA, D.A.; FRANCO, H.C.J.; OTTO, R. Recovery of nitrogen $\left({ }^{15} \mathrm{~N}\right)$ by sugarcane from previous crop residues and urea fertilisation under a minimum tillage system. Sugar Tech, v.13, p.42-46, 2011. DOI: https://doi.org/10.1007/s12355-011-0074-4.

FRANCO, H.C.J.; OTTO, R.; FARONI, C.E.; VITTI, A.C.; OLIVEIRA, E.C.A. de; TRIVELIN, P.C.O. Nitrogen in sugarcane derived from fertilizer under Brazilian field conditions. Field Crops Research, v.121, p.29-41, 2011. DOI: https://doi.org/10.1016/j.fcr.2010.11.011.

FRANCO, H.C.J; TRIVELIN, P.C.O.; FARONI, C.E.; VITTI, A.C.; OTTO, R. Stalk yield and technological attributes of planted cane as related to nitrogen fertilization. Scientia Agricola, v.67, p.579-590, 2010. DOI: https://doi.org/10.1590/S010390162010000500012.

FURLANI, A.M.C. Nutrição mineral. In: KERBAUY, G.B. (Org.). Fisiologia vegetal. Rio de Janeiro: Guanabara Koogan, 2004. p.40-75.

INMAN-BAMBER, N.G.; SMITH, D.M. Water relations in sugarcane and response to water deficits. Field Crops Research, v.92, p.185-202, 2005. DOI: https://doi.org/10.1016/j. fcr.2005.01.023.

JACOBS, D.F.; TIMMER, V.R. Fertilizer-induced changes in rhizosphere electrical conductivity: relation to forest tree seedling root system growth and function. New Forests, v.30, p.147-166, 2005. DOI: https://doi.org/10.1007/s11056-005-6572-z.

LEITE, J.M.; CIAMPITTI, I.A.; MARIANO, E.; VIEIRAMEGDA, M.X.; TRIVELIN, P.C.O. Nutrient partitioning and stoichiometry in unburnt sugarcane ratoon at varying yield levels. Frontiers in Plant Science, v.7, art.466, 2016. DOI: https://doi.org/10.3389/fpls.2016.00466.

MALAVOLTA, E.; VITTI, G.C.; OLIVEIRA, S.A. de. Avaliação do estado nutricional das plantas: princípios e aplicações. Piracicaba: Potafos, 1997. 319p.

MARIANO, E.; LEITE, J.M.; MEGDA, M.X.V.; TORRESDORANTE, L.; TRIVELIN, P.C.O. Influence of nitrogen form supply on soil mineral nitrogen dynamics, nitrogen uptake, and productivity of sugarcane. Agronomy Journal, v.107, p.641-650, 2015. DOI: https://doi.org/10.2134/agronj14.0422.

MARIANO, E.; LEITE, J.M.; VIEIRA-MEGDA, M.X.; CIAMPITTI, I.A.; VITTI, A.C.; FARONI, C.E.; FRANCO, H.C.J.; TRIVELIN, P.C.O. Biomass and nutrient content by sugarcane as affected by fertilizer nitrogen sources. Crop Science, v.56, p.1234-1244, 2016. DOI: https://doi.org/10.2135/ cropsci2015.06.0349. 
MARIANO, E.; TRIVELIN, P.C.O.; VIEIRA, M.X.; LEITE, J.M.; OTTO, R.; FRANCO, H.C.J. Ammonia losses estimated by an open collector from urea applied to sugarcane straw. Revista Brasileira de Ciência do Solo, v.36, p.411-419, 2012. DOI: https://doi.org/10.1590/S0100-06832012000200010.

MEGDA, M.X.V.; MARIANO, E.; LEITE, J.M.; MEGDA, M.M.; TRIVELIN, P.C.O. Chloride ion as nitrification inhibitor and its biocidal potential in soils. Soil Biology \& Biochemistry, v.72, p.84-87, 2014. DOI: https://doi.org/10.1016/j.soilbio.2014.01.030.

MEGDA, M.X.V.; TRIVELIN, P.C.O.; FRANCO, H.C.J.; OTTO, R.; VITTI, A.C. Eficiência agronômica de adubos nitrogenados em soqueira de cana-de-açúcar colhida sem queima. Pesquisa Agropecuária Brasileira, v.47, p.1681-1690, 2012. DOI: https://doi.org/10.1590/S0100-204X2012001200002.

MUNNS, R.; TESTER, M. Mechanisms of salinity tolerance. Annual Review of Plant Biology, v.59, p.651-681, 2008. DOI: 10.1146/annurev.arplant.59.032607.092911.

OTTO, R.; SILVA. A.P.; FRANCO, H.C.J.; OLIVEIRA, E.C.A.; TRIVELIN, P.C.O. High soil penetration resistance reduces sugarcane root system development. Soil and Tillage Research, v.117, p.201-210, 2011. DOI: https://doi.org/10.1016/j. still.2011.10.005.

OTTO, R.; TRIVELIN, P.C.O.; FRANCO, H.C.J.; FARONI, C.E.; VITTI, A.C. Root system distribution of sugar cane as related to nitrogen fertilization, evaluated by two methods: monolith and probes. Revista Brasileira de Ciência do Solo, v.33, p.601-611, 2009. DOI: https://doi.org/10.1590/S0100-06832009000300013.

RAIJ, B. van; ANDRADE, J.C. de; CANTARELLA, H.; QUAGGIO, J.A. (Ed.). Análise química para avaliação da fertilidade de solos tropicais. Campinas: IAC, 2001. 285p.

ROBINSON, N.; BRACKIN, R.; VINALL, K.; SOPER, F.; HOLST, J.; GAMAGE, H.; PAUNGFOO-LONHIENNE, C.; RENNENBERG , H.; LAKSHMANAN, P.; SCHMIDT, S. Nitrate paradigm does not hold up for sugarcane. PLoS ONE, v.6, e19045, 2011. DOI: https://doi.org/10.1371/journal.pone.0019045.
SANTANA, M.J. de; CARVALHO, J. de A.; SOUZA, K.J. de; SOUSA, A.M.G. de; VASCONCELOS, C.L.; ANDRADE, L.A. de B. Efeitos da salinidade da água de irrigação na brotação e desenvolvimento inicial da cana-de-açúcar (Saccharum spp) e em solos com diferentes níveis texturais. Ciência e Agrotecnologia, v.31, p.1470-1476, 2007. DOI: https://doi.org/10.1590/S141370542007000500030 .

SANTOS, H.G. dos; JACOMINE, P.K.T.; ANJOS, L.H.C. dos; OLIVEIRA, V.A. de; LUMBRERAS, J.F.; COELHO, M.R.; ALMEIDA, J.A. de; CUNHA, T.J.F.; OLIVEIRA, J.B. de. Sistema brasileiro de classificação de solos. 3.ed. rev. e atual. Brasília: Embrapa, 2013. 353p.

SOIL SURVEY STAFF. Keys to soil taxonomy. $12^{\text {th }}$ ed. Washington: Usda, 2014. 372p.

TAIZ, L.; ZEIGER, E.; MØLLER, I.M.; MURPHY, A. Fisiologia e desenvolvimento vegetal. 6.ed. Porto Alegre: Artmed, 2017. $888 \mathrm{p}$.

VIEIRA, M.X.; TRIVELIN, P.C.O.; FRANCO, H.C.J.; OTTO, R.; FARONI, C.E. Ammonium chloride as nitrogen source in sugarcane harvested without burning. Revista Brasileira de Ciência do Solo, v.34, p.1165-1174, 2010. DOI: https://doi. org/10.1590/S0100-06832010000400016.

VIEIRA-MEGDA, M.X.; MARIANO, E.; LEITE, J.M.; FRANCO, H.C.J.; VITTI, A.C.; MEGDA, M.M.; KHAN, S.A.; MULVANEY, R.L.; TRIVELIN, P.C.O. Contribution of fertilizer nitrogen to the total nitrogen extracted by sugarcane under Brazilian field conditions. Nutrient Cycling in Agroecosystems, v.101, p.241-257, 2015. DOI: https://doi.org/10.1007/s10705-0159676-7.

WACLAWOVSKY, A.J.; SATO, P.M.; LEMBKE, C.G.; MOORE, P.H.; SOUZA, G.M. Sugarcane for bioenergy production: an assessment of yield and regulation of sucrose content. Plant Biotechnology Journal, v.8, p.263-276, 2010. DOI: https://doi. org/10.1111/j.1467-7652.2009.00491.x. 